\title{
Language obsolescence in polysynthetic languages
}

\section{Gruzdeva, Ekaterina}

Oxford University Press

2017-07-29

Gruzdeva , E \& Vakhtin , N 2017 , Language obsolescence in polysynthetic languages . in M Fortescue , M Mithun \& N Evans (eds), The Oxford Handbook of Polysynthesis . Oxford University Press, New York , pp. 428-448 . https://doi.org/10.1093/oxfordhb/9780199683208.013.24

http://hdl.handle.net/10138/311576

https://doi.org/10.1093/oxfordhb/9780199683208.013.24

acceptedVersion

Downloaded from Helda, University of Helsinki institutional repository.

This is an electronic reprint of the original article.

This reprint may differ from the original in pagination and typographic detail.

Please cite the original version. 


\section{Chapter 27. Language obsolescence in polysynthetic languages}

Ekaterina Gruzdeva, Nikolai Vakhtin

\section{Introduction}

This chapter deals with structural changes in those polysynthetic languages that find themselves in the situation of language shift. The principal question here is: what happens, at different linguistic levels, to a polysynthetic language when it falls out of use, becomes obsolescent and is gradually replaced by a dominant language.

We start with definitions and discussions of key concepts of language obsolescence and the linguistic changes it leads to, and the terminology used here. Next, we discuss how the changes that take place in decaying polysynthetic languages can be distinguished from (a) those changes that occur in all obsolescent languages regardless of their type, and (b) changes in "healthy" polysynthetic languages. In the main part of the chapter, we examine in detail obsolescence-induced structural changes in polysynthetic languages.

\section{Key concepts}

\subsection{Polysynthetic languages and polysynthetic features}

In a series of papers, Fortescue $(1994,2007)$ has distinguished several features (a-d) a language should have to be called 'polysynthetic'1:

(a) complex morphological structure: polysynthetic word forms are characterized by numerous morphological 'slots' and a large inventory of bound morphemes;

(b) head-marking (or double marking) type of inflection:

(i) nominal forms usually bear possessive marking;

(ii) verbal forms typically contain pronominal markers, as well as various integrated adverbial elements; these features allow verbal forms to be used as sentence equivalents;

(c) incorporation: adjectives are incorporated into nominal forms and nouns are incorporated into verbal forms;

One more rather common property of a polysynthetic language is the feature (d):

(d) productive morphophonemics and complex allomorphy of bound and free morphemes.

It is important to note that in this chapter we describe the attrition of polysynthetic features rather than attrition of polysynthetic languages. We assume that similar polysynthetic features

\footnotetext{
1 Some of these features are universal, others are more like statistical universals, or even tendencies. Feature (d) below, for example, is not typical of all polysynthetic languages, cf. e.g. Australian languages Bininj Gun-wok and Dalabon (Evans 2003).
} 
behave in a similar way regardless of whether other subsystems of the language in question are polysynthetic. In other words, we consider a piece of data relevant for our topic even if the language that an example comes from does not have all characteristics of a polysynthetic language: a language may, for example, lack incorporation but still be a relevant source of data for our analysis if it shows morphological complexity.

As Polinsky (1995: 119) mentions, in addressing language attrition and loss it is important to distinguish three types of problem: (a) is there a particular set of linguistic characteristics that are consistently lost across languages? (b) what new linguistic characteristics arise in languages as compensatory for the lost features? and (c) is there a particular set of linguistic characteristics that are consistently retained across languages? This approach provides a convenient pattern also for the analysis of attrition in polysynthetic languages.

\subsection{Language obsolescence and language attrition}

Language obsolescence 2 refers to the process in which a bilingual speech community starts using their second language 3 more often, to the extent that it becomes 'dominant', while their first ('recessive') language gradually loses its functional domains and may eventually be abandoned, first by the younger generation and later by almost the whole community (see Dorian 1981, 1982; Sasse 2001; Dwyer 2011; Aikhenvald 2012). It is hardly possible to give here an exhaustive analysis of the relevant literature; we refer the reader to (Tsunoda 2005), especially to Chapter 8 'Structural changes in language endangerment' (pp. 76-116) where one can find a detailed discussion of the issue (see also Siemund 2008)

Language shift takes place in various political, socioeconomic and cultural contexts (Dorian 1982: 44-48) and can vary in duration from one or two generations (so-called 'catastrophic shift') to several centuries.

It should be noted that in its earlier stages language obsolescence is not easy to diagnose; interpretation of a language situation as language shift often has to rely on the researcher's prognostications and extrapolations (Viktorova 2007)4.

\footnotetext{
2 Terminological inconsistencies are abundant here: the process is also called language loss, shift, death, decay, attrition, decline, contraction, deacquisition (see Craig 1997: 258).

3 In this chapter, we use the terminology suggested in (Sasse 2001: 1669-1670): we use first and second language with respect to order of acquisition; which may or may not correlate with the dominant vs recessive opposition.

4 For a comprehensive review of assessment tools for language endangerment, starting from Joshua Fishman's 1991 Graded Intergenerational Disruption Scale (GIDS) to the 2010 Extended GIDS suggested by Paul Lewis and Gary Simons, see (Dwyer 2011).
} 
The most typical case of language loss is 'gradual death' that goes through several stages. One of the intermediate stages is a well-balanced bilingualism in which the dominant language comes to be employed by an ever increasing number of speakers in a growing number of contexts where the recessive language was formerly used (Campbell and Muntzel 1989: 185).

At the earliest stage of language decay, a recessive language undergoes natural contact changes5, such as (i) convergence or 'negative borrowing', when non-congruent forms disappear from contact languages, and (ii) interference or 'positive borrowing', when new forms and rules are introduced into the language under the influence of another language (Romaine 1995: 72-76; Sasse 1992: 65). 'Positive borrowing' may be further divided into (a) borrowing of substance (transfer of overt markers) and (b) borrowing of patterns (imitation of structural make-up) (Sasse 2001: 1670). As pointed out in (Dorian 1981: 151), “dying languages, to judge by [East Sutherland Gaelic], show [at this early stage. - E.G., N.V.] much the same sorts of change we are familiar with from perfectly ordinary change in "healthy" languages".

Theoretically, this earlier stage of language obsolescence can last for a very long time; language attrition is therefore a possible but not inevitable contact phenomenon.

The terminal stage of language obsolescence is characterized by a radical reduction and total disintegration of the recessive language to the extent that it cannot be used anymore in its communicative function. This terminal stage is not particularly interesting from a pure linguistic point of view, although it is fascinating sociolinguistically. Even a "broken" language can still bear a symbolic function, so that the speakers who only retain a rudimentary knowledge of it may still claim to be speaking it by using individual words or phrases, thus marking their distinctive identities (see, for example, Evans 2001, Vakhtin 2006).

The focus of this chapter is on the middle stage of language obsolescence, which is characterized by various structural changes in the recessive language that go beyond "normal" contact-induced changes. It is important to bear in mind that the process of language loss applies to individual speakers, and many speech communities experiencing language shift exhibit a proficiency continuum scale ranging from (nearly) fully competent speakers down to semispeakers and further to 'rememberers' (Dorian 1981: 117ff; Dressler 1981: 6-7; Campbell and Muntzel 1989: 181; Vakhtin 2001: 113-114). The continuum scale typically correlates with the age of the speakers: the younger generation usually demonstrates lower proficiency in a recessive language than the older one. According to (Sasse 1992: 61), the locus of language decay is the semi-speaker. Semi-speakers themselves form a continuum, since their command of a language is characterized by various degrees of language attrition (see, e.g. Gruzdeva 2007:

5 Contact-induced changes of polysynthetic language (that are also typical of all languages in a contact situation) are examined in Chapter 26. 
25-26). All this makes the recessive language highly variable. Variability in this case, unlike in "normal" situations, does not necessarily bear a sociolinguistic function: variants of forms and structures used by other semi-speakers are not necessarily regarded as positive or negative (Palosaari and Campbell 2011: 111), and may not be registered as deviations at all.

From the generational point of view, language attrition pertains to a decrease in language proficiency (Gardner 1982: 24) that manifests itself in various kinds of reductive phenomena. The younger the speakers are the more sporadic changes they make in their use of a recessive language; these mistakes are noted and often commented upon by older speakers (Aikhenvald 2012: 77).

In trying to explain the rise of attrition, researchers turn to two different cognitive processes: (a) the attrition of the first language as a result of insufficient communication and disuse of the language by adult speakers leading to the forgetting of a language and its gradual loss and (b) an incomplete acquisition of the recessive language by younger speakers due to the break in linguistic tradition (see Andersen 1982: 91; Trudgill 1983: 124-126; Sasse 2001: 1669; Tsunoda 2005: 99). Both processes involve insufficient access to language input (Polinsky 1995: 88) and produce similar outputs.

\subsection{Structural features of language attrition}

Analysing the development of language attrition, researchers pay attention to the quality, quantity and speed of changes that take place in a recessive language.

Language decay typically results in a general simplification and reduction of the recessive language's grammar and lexicon (Trudgill 1983: 124-126; Sasse 1992: 60). These changes especially affect the linguistic features that are not shared by the recessive and dominant languages. As Aikhenvald (2012: 80) points out, "the categories absent from the dominant language are particularly endangered".

Simplification is the elimination of competing structures or their reanalysis as a result of which the language becomes more regular (Romaine 1995). For instance, if the language has three devices for expressing a category, two of them may become redundant. However, such changes just modify the language system and do not influence the speakers' ability to express themselves in this language. Therefore, simplification may be a necessary, but not sufficient, condition for postulating language attrition.

One simplification process that is widely attested in recessive languages and similar to analogical leveling is the regularization of morphophonemics and morphology (Seliger and Vago 1991: 10-11; Sasse 2001: 1671). For instance, in her works on East Sutherland Gaelic, Dorian 
(1973, 1981, inter alia), reports that semi-speakers tend to use only one allomorph of the plural marker (-ən) and correspondingly only one allomorph for deriving a gerund (-al).

Conversely, reduction is characterized by the loss of structural elements without their compensation by other elements from a recessive language (Mühlhäusler 1974). Expressibility may be preserved in the obsolescent language community, but only by partial shift of language functions from the recessive to the dominant language (Trudgill 1974; Dorian 1981: 153ff, 1982: 44; Dressler 1982: 325f, 2011: 89; Giacalone-Ramat 1983: 38).

Describing the (then) young speakers' variety of Dyirbal, an Australian Aboriginal language of northeast Queensland, Schmidt (1985: 213-214) notes that "another distinctive difference between language death and change in healthy languages is that reduction in the dying language is not always compensated for by structural expansion elsewhere in the language system $<\ldots>$ [the speakers] rely on English linguistic resources to fill these gaps".6

Following Dressler (1991: 107) and Schmidt (1991: 119), we argue that reduction is one of the essential features and specific signs of attrition, since along with the structural elements the language loses some of its functions which start being performed by the dominant language. Obviously, the processes of reduction and transition to another language can be regarded as interdependent and representing a self-regulating system.

Reductive phenomena may be observed at different levels and involve various kinds of "losses" pertaining to vocabulary, phonological contrasts, productive word-formation, morphological categories, syntactic structures, styles and registers (Trudgill 1974; Andersen 1982; Campbell and Muntzel 1989; Sasse 2001).

Thus, Central Pomo (Pomoan; Northern California), whose traditional form boasts an elaborate system of verbal markers for specifying various kinds of temporal, causal, and referential relationships between clauses (e.g. switch-reference), exhibits a whole range of morphosyntactic reduction in language obsolescence. Mithun (1990: 13) notes that "the density of these enclitics appears to correlate with the fluency of speakers. The least fluent speaker clearly experienced difficulty in some situations where such markers would normally be used." Furthermore, “...speakers less fluent in Central Pomo do not control the intricacies of case, number, defocus, and clause combining” (Mithun 1990: 13-14).

The destruction of grammatical categories and total disintegration of morphological system is impressively described by Sasse (1992: 70-72) for Arvanitika (an Albanian variety spoken in Greece). In the speech of less competent speakers, the categories of tense, aspect and mood are totally mixed, the particles of future tense and conditional mood are used in confusion,

\footnotetext{
6 Dyirbal in its simplified version (and even in its full version) can hardly be called a polysynthetic language; we mention it here and below as a general example of attrition in a recessive language.
} 
the system of tenses has reduced to the present tense and aorist, the plural forms of nouns are not used any more, and the cases are mixed. When deriving inflectional forms the speakers improvise, sometimes even inventing new morphemes.

Besides simplification and reduction, language attrition in its advanced phase is characterized also by the overgeneralization or undergeneralization of certain features, the tendency to analytism, agrammatism and a drastic increase in phonological and grammatical variability (Sasse 2001: 1671; Palosaari and Campbell 2011). Thus, Campbell and Muntzel (1989: 186) show that less competent speakers tend to overgeneralize marked phonological features in Teotepeque Pipil (Uto-Aztecan language of Central America). Modern speakers use unvoiced [1] not only at the end of the word, as was typical of "healthy" language, but also in other positions, where it was never used before. In general, overgeneralization, attested in many languages, may be considered as an attempt of supporting social identity (Romaine 1989: 378$379)$.

In the course of attrition, complex synthetic constructions are often replaced by analytic constructions (Sasse 2001: 1671). This phenomenon is also typical of polysynthetic languages $(\S 3)$.

One final example of obsolescence-induced change is found in Tlahuica (also called Matlatzinca or Ocuiltec, an Oto-Manguean language of Mexico), where the rule of voicing stops after nasals fails to apply in the speech of semi-speakers, producing free variation, e.g. between $n d$ and $n t$ (Campbell and Muntzel 1989: 189).

Furthermore, the contrast between language change in "healthy" and decaying languages is often seen not only in the kinds of change that take place in a recessive language, but also in the quantity of change, and in the speed with which it occurs (Aikhenvald 2002: 243264).

Thus, the rate of contact-induced changes and the changes that are otherwise considered natural can be accelerated in an obsolescent language comparing to a "healthy" one (Palosaari and Campbell 2011: 111). As a result, “... an obsolescent language may tend to rapidly become structurally similar to the dominant one" (Aikhenvald 2012: 96) or may undergo other fast, not necessarily reductive, changes. For instance, in the endangered Ottawa (an Algonquian language spoken on Walpole Island, Canada) "the person prefix system exhibits variability and loss which was not known in the language as recently as twenty years ago, and which can be attributed to a natural process of vowel syncope" (Fox 2005: 57, cit. by Palosaari and Campbell 2011: 111).

The same phenomena are reported for Young People's Dyirbal: "While the type of change in Young Dyirbal is not unusual, the quantity of change certainly is $<\ldots>$ vast amounts of change are compressed into a short timespan of about 25 years $<\ldots>$ changes occurring in this 
short period are certainly widespread, affecting: the nominal case system; verb tense; some derivational affixes; conjugation membership and the irregular verb yanu; the pronoun paradigm; noun markers and interrogative members; constituent agreement in the NP and verb complex; word order; and the S-O pivot clause linkage device" (Schmidt 1985: 213).

\section{Obsolescence-induced changes in polysynthetic languages}

Thus, syntactic attrition will cause similar results in languages of different types: parataxis, loss of markers of dependent clauses, reduction of the number of markers with an accompanying broadening of functions of those that are preserved, etc. A semi-speaker typically uses a smaller number of syntactic devices than a fully competent speaker of the same language. A semi-speaker preserves and overuses syntactic constructions that more transparently reflect the underlying semantic and syntactic relations. When there is more than one possible surface structure for a given underlying relation, a semi-speaker tends to collapse the different surface structures into one (Andersen 1982).

The most specific feature of a polysynthetic language is that here these changes will be accompanied by the changes in the morphological structure of verbs, because for a polysynthetic language verbal morphology is, by definition, the core of its grammar, cf. 2.1.

In the following sections 3.2-3.4, we concentrate on polysynthetic language morphology and describe mostly those obsolescence-induced changes that are connected with polysynthetic morphosyntax and morphophonemics.

\subsection{Changes in complex morphological structure}

One of the most prominent signs of polysynthetic language attrition is the loss of its complex morphological structure, with effects on verbal and sometimes also on nominal morphology. Inflectional morphology seems to be more stable both for contact-induced and obsolescenceinduced changes. As Comrie (2008: 15) points out, "inflectional morphology is generally, and I believe correctly, held to be one of the least borrowable parts of a language's structure".

On the contrary, derivational morphology, whose richness is one of the most prominent features of a polysynthetic language (Fortescue 1994, 2007), turns out to be more modifiable than inflectional, in particular in the language decay situation.

As Myers-Scotton (2002: 195-223) formulates, semantic (= derivational. - E.G., N.V.) morphemes are not only the first to arrive in language acquisition and in contact situations, but they are also the first to depart in language attrition. In all probability, this is explained by the fact that they are easier to replace: in reduced speech, bound derivational morphemes are often substituted with lexical items, i.e. adjectives, adverbs, particles, etc. 
The following sections 3.1.1-3.1.2 discuss attrition in verbal and nominal inflectional and derivational morphology.

3.1.1. Attrition in verbal morphology of polysynthetic languages. With respect to attrition, verbal morphology is the most vulnerable domain of polysynthetic languages. Non-fluent speakers tend to reduce complex verb structures and get rid of some morphological 'slots', especially when the same category is double-marked.

In Tlahuica, imperfect speakers often eliminate the plural and dual suffixes from the polysynthetic verb forms (indicated in example (1) in parentheses). Note that, in the traditional language, number is marked both by prefixes and suffixes:

(1) Tlahuica (Campbell and Muntzel 1989: 191-192)
a. $\quad k i a t-k w e-p-t y i t(-n k w e(-\beta i))$
FUT-1PL-EXCL-sing(-DU-(EXCL))
'We (two, but not you) will sing.'
b. $\quad k i a t-k w e-p-t y i t(-h \tilde{n} \partial-\beta i))$
FUT-1PL-EXCL-sing(-PL-(EXCL))
'We (all, but not you) will sing.'

The following sections 3.1.1.1-3.1.1.2 consider the changes in verbal inflectional and derivational morphology in more detail.

\subsubsection{Verbal inflectional morphology}

Language attrition affects the basic verbal inflectional categories, such as person, number, tense, aspect and mood somewhat differently.

\subsection{Person and number}

Person and number turn out to be the most stable morphological categories in language loss situations.

This observation may be illustrated by examples from Ainu7, an isolate language of the northern Japanese island of Hokkaido. Here many verbs have different (suppletive) stems for

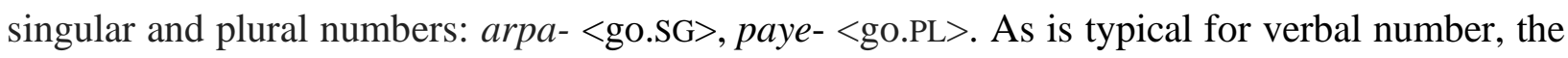
suppletion targets the absolutive argument: for intransitive verbs it is the number of the subject that counts, paye <go.SUBJ.SG> 'many (people) went', while for transitives it is the number of the object: rоппи <kill.OBJ.PL> 'killed many (bears)' .

7 The examples have been kindly provided to us by Anna Bugaeva. 
Semi-speakers of Ainu will first lose verbal number marking, but the inflectional marking for subject and object is much more resilient. In other words, instead of the correct ecipaye 〈2PL.SUBJ-go.PL> 'you.PL went', semi-speakers will say eci-arpa <2PL.SUBJ-go.SG> for 'you.PL went'. However, they will hardly say just arpa, because this would be automatically interpreted as 's/he went', third person singular marker being a zero.

Furthermore, the distinction between transitive and intransitive verbs is also retained to the bitter end. In Ainu, these two classes of verbs partly differ in their person/number paradigms: for example, first person plural markers for the subject of the intransitive verb (S) and the subject of the transitive verb (A) are $-a s<1$ PL.S.INC $>$ and $c i$ - $\langle 1$ PL.A.INC $>$ respectively. Even the least knowledgeable speakers never say *ci-paye <1PL.A.INC-go> instead of paye-as <go-1PL.S.INC> 'we (inclusive) go'. Cf. the following examples, which exemplify the use of A forms:

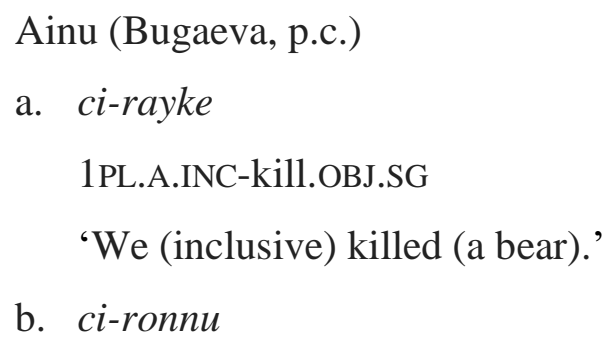

a. ci-rayke

1PL.A.INC-kill.OBJ.SG

'We (inclusive) killed (a bear).'

b. ci-ronnu

1PL.A.INC-kill.OBJ.PL

'We (inclusive) killed many (bears).'

This stability can be explained as follows. In non-polysynthetic languages that allow/require overt NPs, verbal personal marking is an agreement feature. When this agreement is lost, it is a simplification, i.e. loss of redundant complexity. In contrast, in "healthy" polysynthetic languages, person/number marking on the verb is the only place where the NPs are marked: these bound morphemes are the arguments of the verb. Therefore, the loss of personal marking in a polysynthetic language would be a reduction, i.e. loss of an essential structural feature, so the marking is much more tenacious8.

However, even when the person/number marking is retained, the structure of an obsolescent polysynthetic language may change rather radically. As has been already shown, in Kabardian, subject, direct object and indirect object are marked with bound pronominal affixes. As a result, verb forms like in (3a) may function as full clauses. The speakers of reduced Kabardian do not accept such forms as correct full clauses and restore overt pronouns or full NPs, as in (3b):

\footnotetext{
8 However, not all polysynthetic languages behave like Ainu. For example, semi-fluent speakers of Dalabon typically conflate the intransitive and transitive (third person singular object) prefix sets, most likely under the influence of Bininj Gun-wok, where prefixes do not reflect transitivity in these contexts (Evans, p.c.)
} 
(3) Kabardian (Polinsky 1995: 97)

a. $\quad \varnothing-q^{\circ} \partial-s \check{a}-y \partial-t+a-\dot{s}$

3SG.OBJ-to-1SG-3SG.SUBJ-give+PRF-DEC

'S/he gave me that/it.'

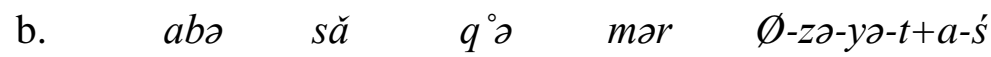

3SG:ERG 1SG to/for it 3SG.OBJ-1SG-3SG.SUBJ-give+PRF-DEC

'S/he gave that to me.'

Another possible scenario is that pronominal markers are retained but they are 'fossilized', i.e. lose their meaning. In Maa (a Nilotic language of Kenya and Tanzania), the category of person/number is expressed by means of different prefixes. In a corpus of material collected by Dimmendaal (1992) from different types of speakers, one non-full speaker of Kore (a Kenyan variety of Maa) generalized the third person singular imperfective tense form with the prefix $\varepsilon$ le-. This prefix no longer functions as a person/number marker, compare (4a) and (4b):

(4) Kore (Dimmendaal 1992: 123)

a. aná-lbàyán $\quad k$-غ́-ðà $\quad$ ggólòy

this-man s-3SG-be sun/hunger

'This man is hungry.'

b. $\quad k$-ć-ðà $\quad$ ggólòy

S-3SG-be sun/hunger

'I am hungry'

In general, examples of loss of personal markers in recessive polysynthetic languages are rare.

\subsection{Tense, aspect, mood}

The loss of morphological complexity may also result in the changes of TAM marking. Here, as in other instances, there is a clear tendency towards analytism. The following examples demonstrate how in Pipil (an Uto-Aztecan language of El Salvador), the traditional synthetic verbal form with the future suffix has been replaced by an analytical one with the verb 'go':

(5) Pipil (Campbell and Muntzel 1989: 192-194)

$\begin{array}{lll} & \text { Traditional form } & \text { Newer form: } \\ \text { a. } & n i \text {-panu-s } & n i-y u \quad n i \text {-panu } \\ & \text { I-pass-FUT } & \text { I-go I-pass } \\ & \text { 'I will pass.' } & \text { 'I will pass.' (lit. 'I am going to pass.') } \\ \text { b. } & \text { ti-panu-ske-t } & \text { ti-yawi- } t \quad \text { ti-panu- } t \\ & \text { we-pass-FUT-PL } & \text { we-go-PL } \quad \text { we-pass-PL } \\ & \text { 'We will pass.' } & \text { 'We will pass.' (lit. 'We are going to pass.') }\end{array}$


Another relevant example is found in Mohegan-Pequot (Rees-Miller 1998). Compared to the speech of the speakers of other Eastern Algonquian dialects, the syntax of the last productive Mohegan-Pequot speaker (1827-1908), was highly analytical. The verbal morphology was extremely uncomplicated with potential, negative, and temporal notions expressed periphrastically by means of particles. This can be seen in particular by comparing the last speaker's version of the Lord's Prayer with the examples recorded in the 17th and 18th centuries. Thus, in the old versions of the sentence 'Give us this day our daily bread', a synthetic imperative form (mesunnan 'give us') containing an ending indicating that the verb is animate transitive with second person actor and first person goal is used, while in a more modern version of the text the main verb mi:zam with the same meaning 'give us' is used without an ending. In another case, imperatives are expressed periphrastically with tcantci: 'must' before the main verb (Rees-Miller 1998: 552-554).

The loss of complexity and productivity in word formation, e.g. the reluctance to combine morphemes within single words, may be further illustrated by a well-known example from Cayuga (an Iroquoian language of Ontario, Canada, and Oklahoma, USA). In the full Ontario variety, cf. (6a), repetitive aspect is marked by a prefix, whereas in the reduced Oklahoma variety, cf. (6b), the same meaning is conveyed by a separate word $e$ : 'again':

Cayuga (Mithun 1989: 248-249)
a. Ontario Cayuga
tosasatkahaté:nih
DU.REPETITIVE-2SG-SEMI.REFLEXIVE-turn.around
'turn back around, re-turn'
b. Oklahoma Cayuga
teskaa:té:ni
$e^{\prime}{ }^{?}$
DU-2SG.A-SEMI.REFLEXIVE-turn.around
again
'turn around again'

\subsubsection{Verbal derivational morphology}

As a result of attrition, less frequent derivational bound morphemes are sometimes lost and their meanings are expressed analytically by adverbs or particles, in many cases borrowed.

This can be illustrated by Siberian Yupik, a highly endangered, if not moribund language (Krauss 1992), where many adverbs were borrowed from the neighboring Chukchi language. In the speech of modern speakers, these borrowed adverbs are used to simplify the sentence structure. In (7a), taken from a folklore text, the meaning 'it is only [small, humble] me' 
is expressed by a morphologically complex verb form, whereas in (7b), said by a young speaker, the equivalent meaning is marked by Yupik adverb wetku that comes back to Chukchi vetku:

(7) Siberian Yupik (adapted from Vakhtin, field notes and Rodionova, 2012)

a. aa whanga-ngina-ghhaag-lleq-u-nga

yes me-ONLY-DIM- FUT- INTR-1SG.SUBJ

'Yes, I will be all alone'

b. wetku unami tagi-lleq-u-q

only tomorrow come-FUT-INTR-3SG.SUBJ

'He will only come tomorrow.'

These borrowed adverbs are further used in both full and reduced speech to substitute bound morphemes in both nouns and verbs. In some cases, the corresponding sentences sound quite normal to full speakers; in others they give a distinct feeling of reduced speech. For instance, instead of the full form (8a) one can hear (8b) that sounds quite correct to full speakers, and, similarly, instead of (9a) one can hear (9b) that full speakers would hardly accept as correct:

(8) Siberian Yupik (adapted from Rodionova 2012)
a. yupig-inagh-estun
aleghqu-qaayug-u-nga
yupik-ONLY-VIAL speak-MOD-INTR-1SG.SUBJ
'I can speak only Yupik.'
b. wetku yupig-estun aleghqu-qaayug-u-nga
only yupik-VIAL speak-MOD-INTR-1SG.SUBJ
'I can speak only Yupik.'

(9) Siberian Yupik (adapted from Rodionova 2012)
a. $\quad y u g$-ina-t
atghhagh-aqe-lghi-t
man-ONLY-3PL
travel-HABIT-PART-3PL.SUBJ

'Only men used to travel there.'
b. wetku yuge-t atghhagh-aqe-lghi-t
only man-3PL
travel-HABIT-PART-3PL.SUBJ

'Only men used to travel there.'

In the course of polysynthetic language attrition, the number of morphological derivational 'slots' can also be reduced. For example, in Bare (a North Arawak language of Venezuela and Brazil) verb forms attested in an earlier corpus contain up to five suffixes, whereas later speakers never used more than one suffix on the verb (Aikhenvald 2012: 85).

In obsolescent Oklahoma Cayuga, the best speaker could use all of the verbal affixes individually, but would hesitate to combine several affixes within a single verb form. When the 
latter was supposed to contain just one other prepronominal prefix, she would use both the repetitive prefix $s$ - and the particle é:? 'again'.

(10) Oklahoma Cayuga (Mithun 1989: 248)
a. aotati'tanyú $u^{\top} u h$
'she beat her up'
b. saqtati'tanyú $\dot{u}^{\text {?:? }}$
'she beat her up again'

But when the number of prepronominal prefixes increased further, the best speaker relied on the separate particle alone to carry the meaning 'again'. An Ontario fluent speaker would have simply combined several prefixes in that context (Mithun 1989: 248-249), see above (6a).

A well described example of changes in verbal morphological structure is represented by Tiwi, a North Australian isolate. Lee (1987) compared traditional Tiwi, as described by Osborne (1974), and its modern variety. At the time of her study, most Tiwi adults were fluent in both Tiwi and English. Tiwi children were growing up with Modern Tiwi and learning it as their first language. In addition, they learn English at school.

The main change that distinguishes traditional Tiwi from Modern Tiwi is the level of morphological complexity of the verb. Traditional Tiwi used to be a prototypical polysynthetic language, while Modern Tiwi is largely isolating, with some inflection. Younger people (age 35 and younger) lost many postbases and substituted them with analytical forms - adverbs and particles (Lee 1987: 2-10).

Example (11) shows a chain of prefixes in Traditional Tiwi. All these prefixes are said to be obligatorily used (Aikhenvald 2007: 6).

(11) Tiwi (Jennifer Lee, p.c., quoted from Aikhenvald 2007: 6)

warta a-watu-wuji-ngi-mangi-rr-akupuraji yiripuwarta

bush 3SG.MASC-morning-CONT-CV-water-CV-fall high.tide

'The high tide is falling [literally 'water-falling'] [exposing the] land (bush)'

As can be seen from Table 1, some 'slots' in the verbal structure $(6,7,9,12,13,18)$ were completely eliminated, two 'slots' $(1,2)$ were merged into one, and for some 'slots' $(4,8$, $15)$, the number of possible functions was reduced.

Table 1. Morphological 'slots' in traditional and modern Tiwi (adapted from Lee 1987: 152-154)

\begin{tabular}{|l|l|}
\hline \multicolumn{1}{|c|}{ Traditional Tiwi } & \multicolumn{1}{c|}{ Modern Tiwi } \\
\hline $1-$ subject & $1+2-$ subject-tense \\
\hline $2-$ tense (non-past / past) & \\
\hline $3-$ locative & $3-$ locative \\
\hline $4-\operatorname{mood} 1-$ subjunctive, frustrative, obligational & $4-\operatorname{mood} 1$ (subjunctive, frustrative) \\
\hline $5-\operatorname{mood} 2-$ irrealis & $5-\operatorname{mood} 2$ (irrealis or negative) \\
\hline
\end{tabular}




\begin{tabular}{|c|c|}
\hline $6-$ temp 1 (in the morning) & \\
\hline \multicolumn{2}{|l|}{7 - direct object/indirect object } \\
\hline 8 - aspect (durative, non-past, inceptive) & 8 - aspect (durative) \\
\hline \multicolumn{2}{|l|}{9 - stance (away from camp, distant in time) } \\
\hline 10 - emphatic & 10 - emphatic \\
\hline $11-$ connective & $11-$ connective \\
\hline \multicolumn{2}{|l|}{$12-$ temp 2 (in the evening) } \\
\hline \multicolumn{2}{|l|}{13 - concomitative } \\
\hline 14 - nucleus (stem + incorporated forms) & 14 - nucleus (no incorporation) \\
\hline $\begin{array}{l}15 \text { - voice (causative, completive, reflexive, } \\
\text { reciprocal) }\end{array}$ & 15 - voice (reciprocal) \\
\hline $16-$ aspect 2 (movement) & $16-$ aspect 2 (durative or beginning) \\
\hline 17 - aspect 3 (repetitive, habitual) & $\begin{array}{l}17 \text { - aspect } 3 \text { (past habitual or } \\
\text { repetitive) }\end{array}$ \\
\hline 18 - locative (same as 1 , but with imperatives) & \\
\hline
\end{tabular}

The loss of morphological elements may be compensated for by borrowing patterns from the dominant language. A striking example of such a development is attested in Tariana, a Northern Arawak language of Brazil. This is a highly endangered language in contact with dominant but genetically unrelated Eastern Tucano languages, particularly Tucano. Tariana loses its verbal prefixes and their corresponding 'slots' following the general tendency to eliminate grammatical categories not found in Tucano and to conform to a general suffixing tendency of the Tucano type. This process is a part of a more general convergence of Tariana towards East-Tucano structures (Aikhenvald 2002: 147).

On the other hand, verb compounding in Tariana appears to be expanding through a mechanism of grammatical calquing (loan translations). Tariana verb roots are reinterpreted as affixes and get spontaneously used as the second components of verb compounds where they follow the fully inflected verb. An example of such process is the way the verbal stem -yena 'little by little' was spontaneously used as a loan translation of the Tucano suffix -tiha 'do little by little' in (12b). After this enclitic was used once, it was picked up by other Tariana speakers, and started being used in a way completely parallel to Tucano -tiha in (12a). Here, the process of language loss has led to the "speeding up" of calquing and thus creating "new morphemes" (Aikhenvald 2002: 149).

(12) (Aikhenvald 2002: 148)

a. Tucano

ba'ã-tiha-mi

eat-DO.LITTLE.BY.LITTLE-3SG.MASC.PRES.VIS

'(The child) is eating little by little.' 
b. Tariana

$$
\begin{aligned}
& \text { emite di-hna-yena-naka } \\
& \text { child 3SG.NF-eat-LITTLE.BY.LITTLE-PRES.VIS } \\
& \text { 'The child is eating little by little.' }
\end{aligned}
$$

\subsubsection{Attrition in nominal morphology of polysynthetic languages}

The obsolescence-induced changes that affect nominal morphology are attested in particular in head-marked possessor constructions and derivational morphology.

\subsubsection{Head-marked possessor constructions}

In the speech of non-fluent speakers the marking of possession on the head noun is often lost either partly or completely which can be illustrated by the following examples.

Formerly, Nivkh kinship terms were construed with obligatory grammatical indication of the possessor. If the latter referred to a singular person, it could be coded by a reduced form of the corresponding personal pronoun, which functions as a prefix, cf. $\tilde{n}$-ətk 'my father', $t$ ' '-amk 'your.SG mother'. If the possessor was dual or plural, a full form of the corresponding personal pronoun in preposition to the noun was used: cf. t ' $i n+a q i 9$ 'your.PL elder brother', in+asq 'their junior brother'. In modern Nivkh, the marking of possessor on kinship terms is gradually vanishing, which may be explained by the strong influence of Russian where the indication to the possessor in these terms is necessary only in the conditions of reference conflict (Gruzdeva 2000: 124).

The last productive speaker of Mohegan-Pequot (an Algonquian language of the southern New England, USA), Mrs. Fidelia Fieding, seems to have lost the full range of possessive forms, as reported in (Rees-Miller 1998: 552-554).

\subsubsection{Nominal derivational morphology}

As has been noted in 2.3, bound derivational morphemes tend to be substituted by lexical items. Whether a morpheme will be still used in reduced speech or not is often a question of frequency. For instance, highly frequent words with evaluative morphemes will continue to be used even by semi-speakers. Thus, in Siberian Yupik, high-frequency magnifying postbase -ghllaq is retained, as in (13a), although some speakers may also say (13b):

(13) Siberian Yupik (Vakhtin, field notes)

a. ama-ghllaq

wolf-MAGN

\footnotetext{
9 In Nivkh, a modifier and a modified form a morphosyntactic complex. The border between lexical items
} entering into the complex is marked by plus. 
'big wolf'

b.

$\begin{array}{ll}\text { ane-lghi } & \text { ama } \\ \text { big-PART } & \text { wolf } \\ \text { 'big wolf' } & \end{array}$

On the other hand, the less frequent postbase -lluk 'old, shabby, worn out' will in all probability be substituted by an adjective, cf. (14a) and (14b)10:

(14) Siberian Yupik (Vakhtin, field notes)
a. kamə-lluk
shoe-OLD
'worn-out shoes'
b. $\quad u t u k a-k$ kamək
old-DU shoe-DU
'worn-out shoes'

\subsection{Changes in noun incorporation}

As has already been noted, polysynthetic languages may represent, in a single verbal form an entire multi-word clause. This may be achieved by using pronominal affixes for some arguments, and incorporated nouns for others (Baker 1996: 19, Evans and Sasse 2002: 2). Noun incorporation, i.e. "the morphological construction where a nominal lexical element is added to a verbal lexical element; the resulting construction being a verb and a single word" (de Reuse 1994: 2842), is a central feature of polysynthetic languages, although it is acknowledged that polysynthesis does not necessarily imply incorporation (Mithun 2009). Chukchi (a ChukotkoKamchatkan language of Russian Far East) is a classic incorporating language: cf. (15a) with unincorporated direct object jakarga-n 'my mouth' and (15b), where it is incorporated into the verb:

Chukchi (Muravieva 2004: 116)
a. gam-nan
jakarga-n
to-lwo-g?e
I-1SG.ERG
mouth-NOM.SG
1SG. SUBJ-burn-PAST.3SG.OBJ
'I burned my mouth.'
b. gəm
tə-jakarga-lwa-g?ek

\footnotetext{
10 Note that sentences like (13b) or (14b) sound ungrammatical because in Siberian Yupik all sentences (with very few exceptions) must contain a verb; the latter can be formed with literally any class of stem, cf. the following example adapted from (Rodionova 2012):

tana yuk utuka-ngu-ft-u-q

this man old-VRBLZR-EVID-INTR-3SG.SUBJ

'It appeared that this man was old.'
} 


\section{I:1SG.NOM 1SG.SUBJ-mouth-burn-PAST.1SG.SUBJ}

'I burned my mouth.'

In cases of polysynthetic language obsolescence, noun incorporation seems to be one of the early victims. The destruction of incorporation starts with the loss of its discourse function (= backgrounding of verbal arguments), followed by the decline of a generic function; 'frozen' (lexicalized) incorporated nouns survive longest of all (Mithun 1984; analyzed in Hill and Hill 1986: 258).

The process has been attested in various recessive polysynthetic languages. For example, Comrie (1981: 250) describes this tendency in Chukchi: "With respect to incorporation ... it should be noted that while this syntactic device is very common in traditional tales, it is much less frequent in current writing, and virtually absent in translations from Russian, i.e. incorporation seems to be on the wane in the modern language." Mithun (1984: 880-881) echoes: "Younger speakers incorporate nouns much less than older speakers; in fact, whenever it is optional, younger speakers usually do not incorporate".

Comparing full (Ontario) and reduced (Oklahoma) varieties of Cayuga, Mithun (1989: 249-250) points out that the speakers of the former easily form complex and rare constructions of the noun incorporation type, while the speakers of the latter use only the frequent ones:

Cayuga (Mithun 1989: 250)
a. Ontario Cayuga
ko-'nohs-owane
F.SG.PAT-onion-large.STATIVE
'She has a big onion.'
b. Oklahoma Cayuga
k-uwane 'nohs-a?
N-big.STATIVE onion-NOMINAL.SUFFIX
'The onion is big.'

The decay of noun incorporation appears to proceed as follows. At a certain point, speakers incorporate fewer new combinations. At first, they may still use noun incorporation frequently in order to background arguments in discourse, but they combine only those nouns and verbs that they have already heard combined. As time goes by, and lexical items are replaced, the repertoire of incorporable nouns and incorporating verbs shrinks, until fewer and fewer noun incorporations are used stylistically in discourse (Mithun 1984: 880).

Obsolescence-induced scenario clearly differs from a "normal" noun incorporation development. The latter was described in (Mithun 2009): the author suggested that at least in some languages, it evolved into what she called 'a noun-suffix construction' (compare Yupik 
examples (18a) and (18b) below). "Over time, the unstressed second members of such constructions, verb roots, lost their individual salience and began to erode further in form. Morphemes which occurred particularly often as second members came to be reinterpreted as suffixes..." (Mithun 2009: 13)11. These Eskimo (and Aleut) noun-suffix constructions apparently recently descended from noun incorporation and "have all of the same attributes and functions of Iroquoian incorporation" (Ibid: 15).

One phenomenon that is ambivalent in terms of its association with attrition is the incorporation of loan words from the dominant language. The pressure of the dominant language may result in incorporating of new borrowed noun stems, as happens, for example, in Mexicano under the influence of Spanish. In (17), the Spanish noun cena 'dinner' is incorporated into the Mexicano verb:

$$
\begin{aligned}
& \text { Mexicano (Hill and Hill 1986: 169) } \\
& \text { ni-quin-cēnah-maca } \\
& \text { I-them-dinner-give } \\
& \text { 'I give them dinner.' }
\end{aligned}
$$

The same is true for borrowed noun stems in Siberian Yupik that are used to form 'root-suffix combinations' (Mithun 2009). In (18), the complex verb is formed by the suffix -ng(e)- 'get, acquire N' with a more general and abstract meaning than the specific 'buy' in the sentences without incorporation. Compare (18a) with a Yupik root and (18b) with a borrowed Russian root hlivuq < хлеб [hleb] 'bread':

(18) Siberian Yupik (Vakhtin, field notes)

$\begin{array}{lll}\text { a. amiraq tukfi-ima- } a & \rightarrow & \text { amira-ng-uma- } q \\ \text { hide buy-PAST-3SG.AG.3SG.OBJ } & & \text { hide-ACQUIRE-PAST-3SG.SUBJ } \\ \text { 'He bought a hide.' } & \rightarrow \quad \text { 'He acquired a hide.' } & \text { hlive-nge-lgha-ten } \\ \text { tukfi-lgha-ten hlivu- } \text { b. } & & \text { bread-ACQUIRE-OPT-2SG } \\ \text { buy-OPT-2SG bread-ABS } & \text { 'Buy (get) bread!' }\end{array}$

In fact, these processes may be interpreted rather as the absence of attrition, since the possibility of incorporating new lexical items proves that the noun incorporation mechanism remains productive.

\subsection{Changes in the allomorphy of bound and free morphemes}

\footnotetext{
${ }_{11}$ Cf., however, the opposite example from Japhug (a Sino-Tibetan language of Eastern Tibet), where an incorporation-like construction is interpreted as the intermediate stage of development from denominal derivation to incorporation (see Guillaume 2012).
} 
Polysynthetic languages are often characterized by productive morphophonemic processes resulting in several allomorphs (phonological shapes) for both lexical stems and bound morphemes (Fortescue 1994: 2601; Mithun 1988: 442). Obsolescence-induced allomorphic reduction can affect the nature of polysynthesis.

A pertinent example comes from Nivkh, where regular consonant alternations take place both at morpheme and word boundaries. The initial consonant of a morpheme/word alternates depending on the final segment of the preceding morpheme/word. For instance, initial consonants of the dative suffix alternate as follows:

$$
\begin{array}{ll}
\text { Nivkh (Krejnovich 1937) } \\
\text { ţax-to } \chi & \text { 'to a top' } \\
\text { tu-ro } \chi & \text { 'into a lake' } \\
\text { mury-do } \chi & \text { 'to a horse' }
\end{array}
$$

One of the basic principles of Nivkh syntax is a special type of 'dependent-head synthesis' that resembles incorporation (Mattissen 2003). The resultant morphosyntactic complexes are subject to morphonological alternations: a modifier brings about alternation in the following head nominal beginning with a plosive, cf. (20a), whereas a primary object triggers an alternation in the following verb beginning with a fricative, cf. (20b):

$$
\text { Nivkh (Krejnovich 1937) }
$$

a. ves+ţoy̆ 'raven's head'

$$
k ə k ə k+z o \eta \check{r} \quad \text { 'swan's head' }
$$

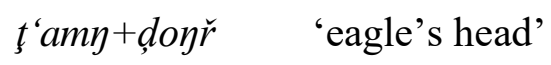

b. $\quad l a q+z o s q-\quad$ break a ski'

$$
\begin{array}{ll}
l u v \check{r}+\text { ţosq- } & \text { 'break a spoon' } \\
\text { niry+ḑosq- } & \text { 'break a cup' }
\end{array}
$$

In modern Nivkh, the system of morphonological alternations has been maintained at the boundaries of morphemes and has partly collapsed at the boundaries of words, especially in phrases with a modifier and head nominal. In the speech of contemporary speakers, initial consonants of head nominals and verbs either do not alternate at all or alternate in a disorderly way and unsystematically. Frequently, the speakers use the free (non-alternating) form in environments where another variant would have been the alternating norm. Thus, modern speakers tend to translate the example 'fish soup' as ţ'o panx, instead of ţ'o + vanx, while the 


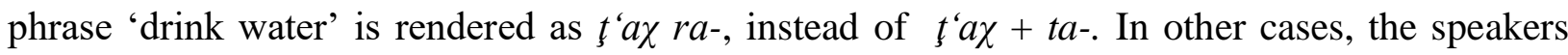
may use both an alternating and a non-alternating variant (i.e. $t^{\prime} o p \partial n x \sim t^{\prime} o+v \partial n x$ ) or otherwise indicated indifference with respect to the quality of the potentially alternating consonant. The language displays a mixed and unregulated pattern of alternations, which leads to the loss of a crucial device for marking polysynthetic complexes (Gruzdeva 2002: 94-95).

\section{Conclusions}

In this chapter, we have presented a variety of data illustrating the process of attrition of polysynthetic features in recessive languages. We set ourselves the task of demonstrating what linguistic features tend to be lost, how these lost features are compensated for and what features are retained across the languages in question.

It has been shown that polysynthetic language attrition is primarily manifested in the collapse of comp51(ha)7(s)-6( )-124(be)7(e)7(n)-20nremilaQq0.0000887 $0595.2584218 \mathrm{eW}^{*} .2587(\mathrm{~m})$ 


Evans, Nicholas and Hans-Jürgen Sasse. 2002. Introduction: Problems of polysynthesis. In: Nicholas Evans and Hans-Jürgen Sasse (eds.), Problems of Polysynthesis. Berlin: Akademie Verlag, 113.

Evans, Nicholas, Janet Fletcher and Belinda Ross. 2008. Big words, small phrases: mismatches between pause units and the polysynthetic word in Dalabon. Linguistics 46.1:87-127.

Fortescue, Michael. 1992. Morphophonemic complexity and typological stability in a polysynthetic language family. International Journal of American Linguistics 58: 2, 242-248.

Fortescue, Michael. 1994. Polysynthetic morphology. In: E.K. Brown, R.E. Asher, and J.M.Y. Simpson (eds.), Encyclopedia of Language and Linguistics, Oxford: Pergamon Press, 2601-2602.

Fortescue Michael. 2007. The typological position and theoretical status of polysynthesis. In: Jan Rijkhoff (ed.), Linguistic Typology. Erhus: Statsbiblioteket Tidsskrift for Sprogforskning, ergang 5.

Fox, Naomi P. 2005. Language Contact on Walpole Island. MA Essay.Wayne State University.

Gardner, Robert C. (1982). Language attitudes and language learning. In: Ellen Bouchard Ryan and Howard Giles (eds.), Attitudes towards Language Variation: Social and Applied Contexts. London: Edward Arnold, 132-147. [Social Psychology of Language 1]

Giacalone-Ramat, Ana. 1983. Language shift and language death. International Journal of the Sociology of Language 17, 495-507.

Gruzdeva, Ekaterina. 2000. Aspects of Russian-Nivkh grammatical interference: The Nivkh imperative. In: Dicky Gilbers, John Nerbonne, and Jos Schaeken (eds.), Languages in Contact. Amsterdam: Rodopi, 121-134. [Studies in Slavic and General Linguistics 28]

Gruzdeva, Ekaterina. 2002. The linguistic consequences of Nivkh language attrition. SKY Journal of Linguistics 15, 85-103.

Gruzdeva, Ekaterina. 2007. Yazykovaya attriciya v sisteme yazykovyh izmenenii [Language attrition in the system of language changes]. In: Nikolai Vakhtin (ed.), Yazykovye izmeneniya $v$ usloviyah yazykovogo sdviga. St. Petersburg: Nestor, 16-58.

Guillaume, Jacques. 2012. From denominal derivation to incorporation. Lingua 122, 1207-1231. [http://www.academia.edu/1627216/Erom_denominal_derivation_to_Incorporation]

Hill, Jane. 1983. Language death in Uto-Aztecan. International Journal of American Linguistics 49:3, $258-276$.

Hill, Jane and Kenneth Hill. 1986. Speaking Mexicano: The Dynamics of Syncretic Language and Central Mexicano. Tucson: The University of Arizona Press.

Krauss, Michael. 1992. The world's languages in crisis, Language 68: 1, 4-10.

Krejnovich, Eruhim A. 1937. Fonetika nivhskogo (giljackogo) jazyka [Nivkh (Giljak) phonetics]. Moskva, Leningrad: Uchpedgiz.

Lee, Jennifer R. 1987. Tiwi Today: A study of language change in a contact situation. Pacific Linguistics. Series C. No. 96. Canberra: Australian National University.

Mattissen, Johanna. 2003. Dependent-Head Synthesis in Nivkh. A Contribution to a Typology of Polysynthesis. Amsterdam; Philadelphia: John Benjamins.

Mithun, Marianne. 1984. On evolution of noun incorporation. Language 60: 4, 847894.

Mithun Marianne. 1988. System-defining structural properties in polysynthetic languages. Zeitschrift für Phonetic, Sprachwissenschaft, und Kommunikationsforschung 41.4, 442452.

Mithun, Marianne. 1989. The incipient obsolescence of polysynthesis: Cayuga. In: Nancy C. Dorian (ed.), Investigating Obsolescence: Studies in Language Contraction and Death. Cambridge: Cambridge University Press, 243257 [Studies in the Social and Cultural Foundations of Language 7]

Mithun Marianne. 1990. Language obsolescence and grammatical description. International Journal of American Linguistics 56:1, 1-26.

Mithun Marianne. 2009. Polysynthesis in the Arctic. In: Marc-Antoine Mahieu, Nicole Tersis (eds.) Variations on Polysynthesis: The Eskaleut Languages. Amsterdam; Philadelphia: John Benjamins, 3-17.

Mühlhäusler, Peter. 1974. Pidginisation and simplification of language. Pacific Linguistics. Series B, Vol. 26. Canberra: Australian National University.

Muravieva, Irina A. 2004. Tipologiya inkorporatsii [Typology of Incorporation]. Doctor of Science Dissertation. Moscow: Rossijskii gosudarstvennyi gumanitarnyi universitet (manuscript).

Myers-Scotton, Carol. 2002. Contact Linguistics, Bilingual Encounters and Grammatical Outcome. New York: Oxford University Press. 
O'Shannessy, Carmel. Language contact and change in endangered languages. In: Peter K. Austin and Julia Sallabank (eds.), The Cambridge Handbook of Endangered Languages. Cambridge: Cambridge University Press, 78-99.

Osborne, Charles R. 1974. The Tiwi language. Canberra: Australian Institute of Aboriginal Studies.

Palosaari, Naomi and Lyle Campbell. 2011. Structural aspects of language endangerment. In: Peter K. Austin and Julia Sallabank (eds.), The Cambridge Handbook of Endangered Languages. Cambridge: Cambridge University Press, 100-119.

Polinsky, Maria. 1995. Cross-linguistic parallels in language loss. Southwest Journal of Linguistics 14, 87-124.

Rees-Miller, Janie. Stages in the obsolescence of certain Eastern Algonquian languages. Anthropological Linguistics 40:4, 535-569.

Rodionova, Natalia. 2012. Russko-eskimosskii slovar' [Russian-Eskimo dictionary] (manuscript).

Romaine, Suzanne. 1989. Pidgins, creoles, immigrant, and dying languages. In: Nancy C. Dorian (ed.), Investigating Obsolescence: Studies in Language Contraction and Death. Cambridge: Cambridge University Press, 369 383. [Studies in the Social and Cultural Foundations of Language 7]

Romaine, Suzanne. 1995. Bilingualism, 2nd edition. Oxford: Blackwell.

de Reuse, Willem. 1994. Siberian Yupik Eskimo. The Language and its Contacts with Chukchi. Salt Lake City: University of Utah Press.

Sasse, Hans-Jürgen. 1992. Theory of language death. In: Matthias Brenzinger (ed.), Language Death: Factual and Theoretical Explorations with Special Reference to East Africa. Berlin; New York: Mouton de Gruyter, 7 30. [Contributions to the Sociology of Language 64]

Sasse, Hans-Jürgen. 2001. Typological changes in language obsolescence. In: Martin Haspelmath et al. (eds.), Language Typology and Language Universals: An International Handbook. Berlin; New York: Mouton de Gruyter, 1668-1677.

Schmidt, Annette. 1985. Young People's Dyirbal: An Example of Language Death from Australia. Cambridge: Cambridge University Press.

Schmidt, Annette. 1991. Language attrition in Boumaa Fijian and Dyirbal. In: Herbert W. Seliger and Robert M. Vago (eds.), First Language Attrition. Cambridge: Cambridge University Press, 11324.

Siemund, Peter. 2008. Constraints and common paths of contact-induced language change. In: Peter Siemund and Noemi Kintana (eds.), Language Contact and Contact Languages. Amsterdam; Philadelphia: John Benjamins, 3-11. [Hamburg Studies in Multilingualism 7]

Trudgill, Peter. 1974. Sociolinguistics: An Introduction. Harmondsworth: Penguin Books.

Trudgill, Peter. 1983. On Dialect: Social and Geographical Perspectives. Oxford: Blackwell.

Tsunoda, Tasaki. 2005. Language Endangerment and Language Revitalization. Berlin; New York: Mouton de Gruyter. [Studies and Monographs 48]

Vakhtin, Nikolai. 2001. Yazyki narodov Severa v 20 veke: ocherki yazykovogo sdviga [Languages of the Far North on the 20th Century: Essays on Language Shift]. St Petersburg: Dmitrii Bulanin.

Vakhtin, Nikolai. 2006. The language of Markovo old settlers: From a communication System to a demo versio. In: Dieter Stern and Christian Voss (eds.), Marginal Linguistic Identities: Studies in Slavic Contact and Borderline Varieties. Wiesbaden: Harrassowitz Verlag, 135-147. [Eurolinguistische Arbeiten. Herausgegeben von Uwe Hinrichs unter Mitarbeit von Uwe Buettner 3]

Vakhtin, Nikolai. 2013. Yazykovye kontakty i russko-eskimosskaya grammaticheskaya interferentsiya: predislovie $\mathrm{k}$ teme [Language contacts and Russian-Eskimo grammatical interference: An introduction to the theme]. In: Nikolai Vakhtin and Elena Perekhvalskaya (eds.), Trudy Instituta lingvisticheskih issledovanii RAN. Vol. 9. Part 3. Collection of papers to the 60th birthday of Evgenii Golovko. St. Petersburg: Nauka. 2013, 347-361.

Viktorova, Kseniya. 2007. Yazykovoi sdvig kak sotsiolingvisticheskoe yavlenie [Language shift as a sociolinguistic phenomenon]. In: Nikolai Vakhtin (ed.), Yazykovye izmeneniya $v$ usloviyah yazykovogo sdviga. St. Petersburg: Nestor, 59-85.

Williams, Robert S. 1999. Referential tracking in Oklahoma Choctaw: Language obsolescence and attrition. Anthropological Linguistics 41:1, 54-74. 


\section{A list of abbreviations}

\begin{tabular}{|c|c|}
\hline ABS & absolutive \\
\hline AG & agent \\
\hline CAUS & causative \\
\hline CVB & converb \\
\hline DAT & dative \\
\hline DEC & declarative mood \\
\hline DIM & diminutive \\
\hline $\mathrm{DU}$ & dual \\
\hline ERG & ergative \\
\hline EVID & evidentialis \\
\hline EXCL & exclusive (plural) \\
\hline $\mathrm{F}$ & feminine gender \\
\hline FIN & finite \\
\hline FUT & future tense \\
\hline HABIT & habitual (actionsart) \\
\hline INC & inclusive \\
\hline IND & indicative \\
\hline INTR & intransitive \\
\hline LOC & locative \\
\hline MAGN & magnifying affix \\
\hline MASC & masculine \\
\hline MED & medial voice \\
\hline MOD & modal suffix \\
\hline $\mathrm{N}$ & noun class?? \\
\hline NEG & negative \\
\hline NOM & nominative \\
\hline $\mathrm{NP}$ & noun phrase \\
\hline OBJ & object \\
\hline OLD & suffix meaning 'bad', 'shabby' \\
\hline OPT & optative \\
\hline PART & participle marker, participial \\
\hline PAST & past tense \\
\hline PAT & patientive \\
\hline PL & plural \\
\hline POSS & possessive \\
\hline $\mathrm{PP}$ & past participle \\
\hline PRES & present tense \\
\hline PRF & perfect \\
\hline PRTCP & participle \\
\hline REFL & reflexive \\
\hline REP & repetitive \\
\hline SG & singular \\
\hline SUBJ & subject \\
\hline TAM & tense, aspect, mood \\
\hline TRNS & transitive \\
\hline VIAL & vialis (case) \\
\hline VIS & visual \\
\hline VRBLZR & verbalizer \\
\hline
\end{tabular}




\begin{abstract}
(short)
This chapter describes what happens at the structural level to polysynthetic languages in the situation of language shift. The changes that take place in decaying polysynthetic languages should be distinguished from (a) those occurring in all obsolescent languages regardless of their type, and (b) changes in "healthy" polysynthetic languages. It is shown that the consequences of polysynthetic language decay is primarily manifested in the collapse of complex morphological structure, involving the loss of morphological 'slots', the reduction in the number of bound morphemes and their substitution by the free ones, the 'fossilization' of markers and their reanalysis, the deprivation of word formation productivity, the destruction of noun incorporation and allomorphic reduction.
\end{abstract}

